\title{
Tanulmányok
}

\section{NAGYHATALMAK ÉS GYENGE ÁLLAMOK A NEMZETKÖZI TÉRBEN}

\section{GREAT POWERS AND WEAK STATES IN INTERNATIONAL POLITICS}

\author{
Borhi László \\ az MTA doktora, MTA Bölcsészettudományi Kutatóközpont Történettudományi Intézete, Department of Central Eurasian Studies, \\ Hamilton-Lugar School of Global and International Studies, Indiana University, Bloomington, IN, USA \\ Iborhi@indiana.edu
}

\begin{abstract}
ÖSSZEFOGLALÁS
E rövid tanulmány azt tárgyalja, hogy gyenge államok képesek-e befolyásolni a nemzetközi politikát, illetve teljesen kiszolgáltatottak-e a nagyhatalmak törekvéseinek. E kérdésre nem lehet egyértelmű igennel vagy nemmel válaszolni. Vannak olyan történelmi helyzetek, amelyekben az olyan kis államoknak, mint Magyarország, nincsen befolyásuk saját sorsukra, máskor azonban akár a nemzetközi politika formálói is lehetnek. Legtöbbször azonban a két véglet között van az igazság, és a viszony kis államok és nagyhatalmak között nem írható le úgy, hogy az előbbiek alárendeltségi viszonyban állnak az utóbbiakkal. A nagyhatalmak védelmet és más szolgáltatásokat nyújtanak gyengébb szövetségeseiknek, és cserében elvárják és kikényszerítik, hogy azok elvárásaiknak megfelelően ellenszolgáltatásokat nyújtsanak nekik, illetve érdekeiknek megfelelően lépjenek fel a nemzetközi politikában. Mindez nem mindig jelenti azt, hogy a nagyhatalmak korlátlanul irányíthatják klienseiket. Időről időre a kisebb hatalmak szembeszegülnek nagyhatalmi patrónusaikkal, és még arra is képesek lehetnek, hogy olyan lépésekre kényszerítsék őket, amelyek kockázatot jelentenek számukra. Az Egyesült Államok elnöke beavatkozott a vietnami konfliktusba, hogy megőrizze országa tekintélyét mint a szabad világ vezető hatalma, Leonyid Brezsnyev pedig ugyancsak országa presztízsszempontjai miatt Észak-Vietnam mellé állt, holott a Szovjetuniónak politikai és gazdasági érdeke volt a szovjet-amerikai viszony rendezése.
\end{abstract}

\section{ABSTRACT}

This paper will discuss the agency of weak states in international politics. In certain historical junctures weak states may not be masters of their own fate, while there are instances when they may even shape international politics. More often than not, however, the truth is somewhere between these two extremes. Powerful states provide protection for their weaker clients in return for a variety of services and loyalty to them in international matters. This may not mean that the great powers are always able to manipulate their clients at their will. From time to time weak states are able to exploit their importance to the dominant power and force them to incur risks on their behalf. Thus for instance the United States intervened on behalf of South Vietnam 
to preserve its prestige and credibility as the leader of the Free World, while Leonid Brezhnev lent political support to North Vietnam for prestige reasons even though the Soviet Union had political and economic motivations to mend fences with the Americans.

Kulcsszavak: biztonság, dominancia, érdekszféra, fluktuáció, hatalom, gyenge állam, nem szándékolt következmény, realizmus, uralom

Keywords: domination, fluctuation, mastery, power, realism, security, sphere of influence, unintended consequence, weak state

Az erő, akárcsak a gyengeség, viszonylagos. Amikor a jaltai konferencián Winston Churchill szóba hozta a Vatikánt, Sztálin megkérdezte, vajon hány hadosztálya van a pápai államnak. Az említett államalakulat ugyan minden bizonnyal elmaradt a Szovjetuniótól a hatalomnak ebben a kritériumában, vonzereje, más szóval az általa birtokolt soft power azonban felülmúlta Moszkváét. Ha ezen a téren is erős a bolsevik állam, talán még ma is létezhetne a Szovjetunió és európai érdekszférája, hiszen a hatalom fontos fokmérőjének számító katonai potenciál tekintetében a Szovjetunió még a felbomlása előtt is a második volt a világon. Az is igaz, hogy gazdasági ereje messze elmaradt fó vetélytársáétól, hiszen 1960 és 1980 között a világ össztermelésének 12 százalékát adta, míg az Egyesült Államok ennek a dupláját. Az erő, akárcsak a gyengeség viszonylagos. Lichtenstein pénzügyi nagyhatalom, ám ez aligha mondható el katonai erejéröl, és nem pont erre az államra gondolunk, amikor „,nagyhatalmakról” beszélünk. A két világháború közötti Csehszlovákia gazdasági és katonai nagyhatalom volt Magyarországhoz képest, azonban képességei messze elmaradtak az akkori szuperhatalom, Németország mögött.

A hatalom viszonylagossága miatt célszerünek látszik azokat az államokat „gyengének” tekinteni, amelyek a 20. század során más állam vagy államok fennhatósága alatt álltak. Ezen a ponton fontos különbséget tenni a külső uralom formái között. A nyugat-európaiak gyakran érezték, főleg amikor a számukra nem tetsző biztonságpolitikai döntés született, hogy az Egyesült Államok fennhatósága alatt állnak. A neves brit politológus, Hedley Bull besorolását elfogadva azonban Nyugat-Európában amerikai uralom (mastery), a kontinens keleti felében viszont szovjet dominancia, majd később, a hatvanas évektől, hegemónia érvényesült (Bull, 1977). Az uralom két utóbbi formája a szuverenitás elvesztését feltételezi, hiszen ezekben az esetekben a helyi kormányzat külső forrás igénybevételével tartja fenn a hatalmát. A dominancia kritériuma sem támadhatatlan, hiszen a még manapság is közepes hatalomnak mondott, ám abban az időben nagyhatalomnak minősülő Franciaország a második világháború alatt öt éven át német uralom alatt állt. Ennek ellenére használható lehet gyengének tekinteni 
azokat az államokat, melyeknek sorsa huzamosabb ideig idegen hatalmak döntéseinek volt a függvénye.

A nemzetközi kapcsolatok története leginkább a nagyhatalmak harcát mutatja be a hatalomért, illetve a biztonságért. E két elem ugyanannak az éremnek a két oldala, hiszen ami az egyik nézőpontból a biztonságra irányul, a másikból agreszsziónak látszik (Jervis, 2002). A realista külpolitikai iskola szerint a nemzetközi tér struktúráját csak a nemzetközi politika szereplöi, a nemzetállamok közötti hatalom eloszlásának változásai hozzák létre. Egyesek szerint a nemzetközi politika központi kormányzat híján anarchikus, és hajlamos a fegyveres konfliktusra. Ezzel szemben Marc Trachtenberg úgy véli, hogy a nagyhatalmak érdeke a konfliktusok békés rendezése, és amennyiben kizárólag hatalmi szempontokat vesznek figyelembe, a nemzetközi rendszer önszabályozó, tehát békés is lehet (Trachtenberg, 2012). Mindenesetre a nemzetközi politika „biliárdgolyó” modellje szerint a hatalmi tér szereplői külső behatásokra reagálnak, és a belső berendezkedésüket nem veszi figyelembe.

Ez a megközelítés kevés figyelmet szentel a nemzetközi politika jelentéktelenebb résztvevőinek, holott ismert, hogy kis államok időről időre képesek arra, hogy befolyásolják a nagyhatalmak viselkedését. Ausztria, amely a második világháború után négyhatalmi megszállás alá került, fontos volt a nyugati biztonság szempontjából. Sebezhetőségét kihasználva Ausztria képes volt jelentős amerikai gazdasági segélyt kicsikarni, olyannyira, hogy egy főre számítva Ausztria kapta a legnagyobb amerikai segélyt a második világháború után. Ez a lehetőség a kizárólagosan szovjet megszállás alá került Magyarország számára nem volt nyitva. Moszkva számára Magyarország, a Nyugat részére pedig Ausztria megtartása látszott fontosnak. Saját gyengeségét aknázta ki 1961-ben az NDK is. Ekkor drámai mértékben megemelkedett a Nyugat-Berlinen keresztül az NSZK-ba távozó keletnémet lakosok száma. Ez pedig létében fenyegette a kommunista német államot. Walter Ulbricht számára kézenfekvő volt a megoldás: meg kell szüntetni a város keleti és nyugati fele közötti átjárhatóságot. Akaratát sikerült érvényesítenie annak ellenére, hogy a négyhatalmi ellenőrzés alatt álló város két részének fallal történő elhatárolása megszegte a nagyhatalmak között fennálló megállapodást, mely szerint Berlin helyzetét csak közös megállapodással lehet megváltoztatni. Ulbricht rávette Hruscsov szovjet pártfötitkárt a berlini fal puccsszerü felépítésére. Hruscsov annak ellenére járult hozzá Ulbricht elgondolásához, hogy ezzel szovjet-amerikai összecsapást kockáztatott. A hatalma teljében levő Szovjetunió nem akarta elveszteni legfontosabb szövetségesét, amely szovjet beavatkozás nélkül nem volt életképes.

Ám nem kizárólag stratégiai érdekek révén tarthatják markukban a kisebb országok nagyhatalmi támogatóikat. Dél-Vietnamban aligha volt az Egyesült Államoknak különösebb biztonsági érdeke, gazdasági pedig különösen nem, a két országot korábban nem kötötte össze semmilyen érdek, kulturális vagy történel- 
mi hagyomány. A kommunista világösszeesküvéstől rettegő amerikai vezetés azonban végzetes következményt vizionált arra az esetre, ha a védnöksége alatt álló dél-vietnami állam kommunista és ezen keresztül kínai vagy szovjet befolyás alá kerül. De a vietnami fegyveres beavatkozásban más szempontok is szerepet játszottak, olyanok, amelyek a mai napig kétségessé teszik azon tétel igazát, mely szerint a nagyhatalmak kényükre-kedvükre befolyásolhatják a nekik kiszolgáltatott szövetségeseket. A washingtoni vezetés, Johnson elnökkel az élen nem akarta megengedni magának, hogy cserbenhagyja szövetségesét, hiszen ezzel csorbult volna a szabad világ vezetö hatalmaként élvezett tekintélye. Elveszthette volna megbizhatóságát is szövetségesei, valamint más, egyik irányban sem elkötelezett államok szemében, ami Moszkva malmára hajthatta volna a vizet. Ezen megfontolásokat kihasználva a korrupt és inkompetens dél-vietnami vezetés képes volt fokozatosan katonailag is belehúzni az USA-t északi szomszédjával folyó konfliktusába, annak ellenére, hogy az amerikai hírszerzés szerint nem volt megnyerhető a háború. Észak és Dél konfliktusa befolyásolta a szovjet politikát is. Moszkva érdekelt volt a kelet-nyugati konfliktus tompításában és a kereskedelmi kapcsolatok fejlesztésében. Ezt a törekvést zavarta meg az amerikai intervenció. Moszkva nem engedhette meg magának, hogy vetélytársa, Kína tünjön fel a nemzetközi kommunista mozgalom vezetö hatalmának, ezért kénytelen volt kiállni vietnami szövetségesei mellett annak ellenére, hogy a szovjet vezetés szkeptikus volt a vietnami kommunisták győzelmi esélyeit illetően. Nem véletlen, hogy a szovjet vezetés Peking rosszallása ellenére kompromisszumos békét szeretett volna Hanoi és Washington között, hiszen katonai és gazdasági érdeke a szovjet-amerikai viszony rendezését és nem kiélezését diktálta. Az amerikaiak vietnami fiaskójánál is rosszabbul járt Sztálin Észak-Koreával. Bár nincsen teljes egyetértés a történészek között abban a tekintetben, hogy ki kit manipulált a koreai háború kirobbanásakor, úgy tűnik, nem volt egyértelmü, kié a domináns szerep Kim Ir Szen és a szovjet vezetők kapcsolatában. Annyi bizonyosnak látszik, hogy Kim sikerrel győzte meg a vonakodó Sztálint, hogy forradalmi helyzet van Korea déli részén, és ezért támogassa a Szöul ellen indított offenzívát. Mivel az Egyesült Államok megvetette a lábát Japánban, Sztálin azt remélte, hogy a várt északi győzelem megerősíti a szovjet biztonságot. Dean Acheson amerikai külügyminiszter 1949-ben elmondott beszédében Koreát nem nevezte meg olyan területként, amely az amerikai biztonság részét képezi, így a moszkvai vezetés azzal számolt, hogy az Egyesült Államok semleges marad a konfliktusban. A szovjet biztonság érdekében támogatott háború balul sült el. München és a Hitler megbékítésére irányuló chamberlaini politika emlékezetes kudarca éreztette hatását. Washington úgy értelmezte, hogy a koreai támadást maga Sztálin rendelte el, és az része egy kommunista mestertervnek a világ leigázására. A koreai háború miatt kezdett bele az Egyesült Államok a fegyverkezési versenybe, amely végül térdre kényszerítette riválisát. Bár a nukleáris 
és hagyományos haderőre történő nyakló nélküli költekezést nem minden szakember teszi közvetlenül felelőssé a szovjet rendszer összeomlásáért, a fegyverkezési verseny aláásta a kommunista nagyhatalom gazdasági erejét. A koreai háború tehát nagyobb biztonság helyett - hosszú távon - valószínủleg a szovjet összeomlást siettette.

Hasonlóan járt a közepes hatalomnak számító Ausztria-Magyarország, melynek végzetét nem nagyhatalmak, az oszmánok vagy a poroszok okozták, hanem egy kis balkáni ország. A Szerbia ellen indított offenzíva a Monarchia integritását és biztonságát volt hivatott erősíteni, ehelyett a világháború révén a felbomlásához vezetett. A nagyhatalmi határozatlanság és a kis országok hatalmi törekvéseinek és nacionalizmusának kedvezőtlen egyvelege okozta Közép-Európa két világháború közötti instabilitását. Egy történész megjegyezte, hogy a háború után Párizs volt a világ kormányzati központja, de hatalma soha sem volt akkora, amilyennek akkor és azóta elképzelték, és az ott összegyült államférfiak képtelenek voltak irányítani az eseményeket. A győztes utódállamok legalább akkora szerepet játszottak a háború utáni rendezésben, mint Lloyd George vagy Clemenceau. Eduard Benešnek hatalmas befolyása volt az antantra, illetve a csehszlovák határok kijelölésére. Bár az antanthatalmak a független nemzetállamok létrehozásától az európai stabilitás és biztonság erősödését várták, ez nem következett be. Sőt, egy magas rangú brit diplomata, Sir Robert Vansittart úgy látta, hogy „,mindezen államok, mint például Franciaország, megszállottan igyekeznek mindent megtartani, amit a háború eredményeként kaptak, és fenntartani a status quot azokkal a szomszédokkal szemben, akiket kiraboltak [...]. Románia és Jugoszlávia a nemzetiségi konfliktusok [...] és a felelőtlen sovinizmus miatt megbízhatatlan szövetséges az elérhetetlen biztonságért folyó küzdelemben” (Lojkó, 2010).

Három utódállam, Románia, Jugoszlávia és Csehszlovákia szövetkezett egymással a magyar revíziós törekvések ellen. Rendhagyó szövetségi rendszer volt, hiszen az ország, amely ellen irányult, a szövetség minden egyes tagállamánál gyengébb volt. Általában olyan, fenyegető hatalommal szemben szövetkeznek sebezhető államok, amely a szövetségi rendszer minden egyes tagjánál, sőt, a tagállamok összességénél is erősebb. A belső ellentétek által gyötört Kisantant nem volt képes stabilizálni a Németország és a Szovjetunió között elterülö területet. Nem véletlen, hogy a brit külpolitika a második világháború előestéjére arra jutott, hogy a német nagyhatalmi hegemónia elfogadható megoldás a térség számára. A Foreign Office befolyásos tanácsadója, a történész E. H. Carr úgy vélte, hogy a térségen a Szovjetuniónak és Németországnak kell osztoznia. Chamberlain politikája akár egy tudatos külpolitikai irányvonalként is értelmezhető, melynek az volt a célja, hogy a brit politika számára nem elsődleges fontosságú térséget átengedje a német hegemónia stabilizáló erejének. 
Az eddigiekben a kis államok lehetőségeiről esett szó a nemzetközi politikában. A továbbiakban az 1942 és 1989 közötti korszakot tekintjük át Magyarország példáján keresztül, amikor a közép-európai kis államok nem voltak saját sorsuk irányítói. Elöször nézzük a sokat emlegetett kiugrás problémáját. Ismert, hogy 1942 nyarától először Magyarország, majd Románia, Finnország és Bulgária titkos csatornákon keresztül felvette a kapcsolatokat a szövetséges hatalmakkal, föként az Egyesült Államokkal és Nagy-Britanniával. Elterjedt nézet Kállay Miklós miniszterelnöknek tulajdonítani a magyar kiugrási kísérlet kudarcát, de a vonatkozó iratanyag arra utal, hogy a szövetségeseket nem érdekelte az a lehetőség, hogy leválasszák Németországról a csatlós hatalmakat. Változás a szövetségesek álláspontjában akkor következett be, amikor 1943 kora őszén a quebeci konferencián megállapodtak, hogy a második front megnyitására Normandiában kerül sor, az eredeti terv szerint 1944 májusában. Hirtelen fontos lett a csatlós államok kiválása, amit azok a kedvező békefeltételek reményében egyre inkább sürgettek. A partraszállás sikere érdekében gondoskodni kellett arról, hogy minél kevesebb német egység legyen a helyszínen azzal, hogy a németeket csapataik kivonására kényszerítik. Ezt úgy is el lehetett érni, ha csatlósai árulása miatt Hitler rákényszerül, hogy megszállja őket. Ennek megfelelően az egyesített vezérkari fönökök 1943. novemberi döntése értelmében ki kellett kényszeríteni Magyarország és Románia kiugrását a háborúból „,még abban az esetben is, ha ez német megszállással jár.” Öfelsége kormányának az volt a politikája, hogy „elérje Magyarország megszállását” oly módon, hogy „diszkreditálja a magyar vezetést a németek szemében." Megkockáztatható tehát az a következtetés, hogy az akkori magyar vezetés számára nem volt lehetőség az ország szuverenitásának fenntartására. A kiugrás sikerének vagy kudarcának kulcsa nem Budapesten volt. Sőt, a béketapogatózásokat a partraszállás sikere érdekében arra használták fel, amit Kállay leginkább szeretett volna elkerülni: az ország német megszállására.

Sztálin 1940 novemberében bejelentette igényét a Balkán, különösen Románia és Bulgária ellenőrzésére. Molotov azonban hiába vetette fel az ötletet Hitlernek, a Führer hallani sem akart erről. Mindez nem szegte kedvét a szovjet vezetésnek, mert amikor Eden brit külügyminiszter 1941 decemberében a szovjet fővárosba látogatott, az európai stabilitásra hivatkozva Sztálin bejelentette igényét a kontinens keleti felére. A brit nagyhatalmi státusra tekintettel a britek nem zárkóztak el attól, hogy az érdekszférák elhatárolására törekedve egyezzenek meg a szovjetekkel. A Foreign Office 1943 elején javasolta az amerikaiaknak, hogy egy globális megállapodás keretein belül engedjék át Romániát és a többi, a szovjet határ mellett fekvő országot a „farkasoknak”. Churchill alkuja Sztálinnal 1944 októberében abból a felismerésből fakadt, hogy amerikai támogatás híján olyan megállapodásra kell jutni Moszkvával, amely garantálja a brit birodalmi státust a Közel-Keleten, és konszolidálja Nyugat-Európát. 
Újabb levéltári kutatások fényében érvényét vesztette az a sokak által képviselt álláspont, miszerint a Szovjetunió az amerikai terjeszkedés miatt döntött az általa megszállt területek szovjetizálása mellett. Valójában a szovjet megszállás ténye predesztinálta a megszállt - ha úgy tetszik: felszabadított - országok jövőjét. Egyoldalú volt ugyanis az a történészi megközelítés, amely a szovjet politikát a bolsevizálásra redukálta. Fontos eleme volt a szovjet politikának a hagyományos birodalmi expanzió, melynek eredményeként legkésőbb 1946-ra a megszállt területekböl szovjet katonai és gazdasági tér lett. A Szövetséges Ellenőrző Bizottság szovjet elnöke már 1945-ben eltilthatta nyugati kollégáit az országba történő belépéstől, arra hivatkozva, hogy „ez a mi területünk, és mi mondjuk meg, ki léphet be". 1945-ben született meg az a megállapodás, melynek értelmében a magyar gazdaság legfontosabb részei - a nehézipar, a bányászat és a közlekedés stratégiai ágazatai - szovjet tulajdonba kerültek, ami keleti irányba orientálta a magyar külkereskedelmet. Románia egyébként az európai győzelem napján kötött szinte azonos tartalmú megállapodást Moszkvával. Hans Morgenthau szerint a gazdasági expanzió egyszerre önmagában való cél, illetve a politikai terjeszkedés eszköze (Morgenthau, 1948). Olyan államok esetében, melyek nemzeti össztermékük jelentős részét a külső gazdasági kapcsolatokból realizálják, politikai ellenőrzést jelent, ha egyetlen ország harminc százaléknál nagyobb hányaddal részesedik a külkereskedelmi forgalmából. Nem véletlenül jegyezte meg az amerikai követ 1946 márciusában, hogy a szovjet kontroll erősebb a magyar gazdaságban, mint a német volt, és az ország egy éven belül szovjet gazdasági gyarmattá vált. 1945 eredményeként a szovjet katonai perifériát kiterjesztették Európa szívéig. Katonai értelemben Magyarországot egy 1946. évi egyezmény tagozta be a szovjet katonai térbe, amennyiben a magyar állam költségére biztosította Moszkva számára az ország területének korlátozás nélküli használatát, és ez a megállapodás érdemben később sem változott. Tekintve, hogy a Szovjetunió hatalmas helyi katonai fölénye miatt az Egyesült Államoknak akkor sem lett volna lehetősége arra, hogy szembeszegüljön a Szovjetunióval, ha erre meg lett volna a politikai szándéka, így nehéz elképzelni, hogy külső támasz híján mit tehetett volna a magyar politika másként, hogy elkerülje a betagozódást. Washington és London is a stabilitás szempontjából értékelte a kelet-európai helyzetet. Talán úgy lehetne megfogalmazni álláspontjukat, hogy a nagyhatalmi hegemóniát és kontinentális stabilitást egymást erősítő állapotként kezelték. Washington 1948 után változtatott ezen a filozófián.

A kis államok eszköztelenségét példázza a csehszlovák eset. Benešnél szovjetbarátabb vezető egész Európában nem akadt. Kárpátalját már 1941-ben felajánlotta a Szovjetuniónak, majd 1943 végén barátsági egyezményt kötött a Szovjetunióval. A csehszlovák vezetés az 1938. évi müncheni megállapodás miatt csalódott a nyugati hatalmakban, és Moszkvában látta a biztonság garanciáját. Prága a legjelentéktelenebb külpolitikai kérdésekben is Moszkva mellé állt abban 
a reményben, hogy megőrizheti belpolitikai függetlenségét. Mindez nem volt elég ahhoz, hogy utolsóként bár, de ne kerüljön sor a kommunista hatalomátvételre. Közvetve a prágai puccs történelemformáló szerepet játszott. A berlini blokád mellett ez adta a döntő lökést az amerikai és a nyugat-európai biztonság formális összekapcsolásához.

Tekintve, hogy a szovjet zóna tagállamai külső hatalmi forrást vettek igénybe ahhoz, hogy fenntartsák az uralmukat, kijelenthetö, hogy elvesztették vesztfáliai értelemben vett szuverenitásukat. A szovjet zónába betagozott országok - legalábbis az ötvenes években - felfoghatók sztálinista berendezkedésủ kliensállamokként, melyek politikai, gazdasági és katonai szolgáltatásokat teljesítettek a birodalmi központ számára. Az 1953. évi keletnémet felkelés és az 1956. évi magyar forradalom kudarca rámutatott, hogy a szuverenitás helyreállítására nincsen lehetőség. Nyikita Hruscsov 1956-ban megmondta Tito marsallnak, hogy bármit megtesz Magyarország megtartása érdekében. Ennek okát megvilágítja Mihail Gorbacsov ellenzékének a vádja, miszerint a pártvezető elvesztegeti a második világháborús győzelem területi hozadékát, és a Szovjetunió visszakerül a két világháború közötti perifériára. Vagyis, Moszkva globális hatalmi helyzete a közép-európai érdekszférából táplálkozott. Lényegében a térség a szovjet nukleáris ütőerő foglya volt: külső hatalom csak egy pusztító atomháború kockáztatásával avatkozhatott volna be katonai erővel, abban pedig nem volt érdekelt a szovjet vezetés, hogy az Egyesült Államokkal közösen rendezze a térség sorsát egy átfogó megállapodás keretein belül.

Ebből az amerikai politika levonta a következtetést: a csatlós államok helyzete csak abban az esetben változhat, ha a Szovjetunióban történik változás. Tekintve, hogy a nemzeti szuverenitás nem volt helyreállítható, függetlenedésre kizárólag a szovjet hegemonikus tér keretein belül kerülhetett sor. Jó példa erre Románia, mely a szovjet tömb országai közül a leginkább élt ezzel a lehetőséggel. Bukarest építette ki a legszorosabb politikai kapcsolatokat a NATO-hatalmakkal, nem vett részt a Varsói Szerződés katonai integrációjában. Nicolae Ceauşescu, aki világpolitikai szerepre törekedett, közvetítő szerepet vállalt az arab-izraeli konfliktusban, Vietnamban és a kínai-amerikai viszony rendezésében. Amikor azonban Brezsnyev nem vette igénybe Bukarest szolgálatait a prágai tavasz katonai leverésében, a szovjet vezetés érzékeltette, hogy Ceauşescu politikája is feszegeti a moszkvai türéshatárt. A román hírszerzés szovjet katonai beavatkozástól tartott, s Bukarest megértette az üzenetet.

Aznap, amikor a Szovjetunió felbomlott, talán vigasztalásképpen Bush amerikai elnök levelet fogalmazott a „barátjának” nevezett Mihail Gorbacsovnak. Kijelentette: „közösen felszabadítottuk Kelet-Európát, és egyesítettük Németországot". Amennyiben ez így van, az alátámasztja azt a neorealista álláspontot, miszerint rendszerszintủ változást a nemzetközi tér szerkezetében csak a hatalom eloszlásának változása okozhat a nemzetközi tér szereplői, a nemzet- 
államok között. Vagyis: a nemzetközi politika szereplőinek belső fejleményei nem játszanak szerepet. A szakirodalom jelentős része azt hangsúlyozza, hogy nemzetközi tényezők fontos szerepet játszanak belső struktúrák kialakulásában (Gourevitch, 1978).

Történeti kutatások nem látszanak alátámasztani azt a felfogást, hogy a kommunista rendszerek felszámolását és a kétpólusú világrendszer átalakulását a vezető nagyhatalmak Európa egyesítéséről szóló megállapodása okozta. Kétségtelen, hogy a változáshoz szükséges nemzetközi környezetet Gorbacsov 1987-től folytatott reformpolitikája teremtette meg, valamint az, hogy Gorbacsov nem kötelezte el magát a kommunista rendszerek fegyveres erővel történő fenntartása mellett. A szovjet haderő bevetése egyszerre két helyen még 1956-ban is problémát jelentett volna, amikor pedig a Szovjetunió erejének teljében volt. Ugyanakkor tévedés, amit Gorbacsov szovjet kritikusai állítottak, hogy tudniillik Gorbacsov tudatosan felszámolta a második világháború után létrejött nemzetközi rendszert. Nyilvánosan „közös európai házról” beszélt, ám világossá tette, hogy a külpolitikai átalakulásnak a „második világháború után létrejött realitások” keretein belül kell maradniuk, a Varsói Szerződés pedig sérthetetlen. Sem ő, sem munkatársai nem hagytak kétséget afelől sem, hogy a változásoknak a szocialista rendszer fölényét kell biztosítaniuk.

A NATO-hatalmak számára világos volt, hogy a politikai és gazdasági válsággal küzdő kommunista országoknak mélyenszántó reformokra van szükségük ahhoz, hogy elkerüljék az összeomlást és a térség ezzel járó destabilizálódását. Ugyanakkor a teljes demokratizálódás - és ami ezzel járhatott: a szovjet hegemónia visszaszorulása - veszélyeket is hordozott. Elsősorban a nyugatbarát Gorbacsov bukását. Tartani lehetett egy „balkáni” forgatókönyvtől, a volt szovjet térség teljes anarchiába való süllyedésétől, vagy akár attól is, hogy a szovjet hegemóniát egy nem sokkal kívánatosabb német uralom válthatja fel. A fö szempont azonban a Szovjetunió kérdése volt, hiszen az amerikaiak - Bush elnök retorikája ellenére - ezen a reláción keresztül szemlélték a kelet-európai politikát.

Az amerikai elképzelés tehát hangsúlyozottan nem vonatkozott a Varsói Szerződés felszámolására, hiszen könnyü belátni, hogy ez akár a NATO létét is kockára tette volna. Belpolitikai tekintetben pedig a piacgazdaság fokozatos bevezetését és a politikai átalakulást tartották kívánatosnak, de úgy, hogy a demokratikus pártok a kommunistákkal osztoznak a hatalmon. Ezt az álláspontot osztották Washington szövetségesei is, valamint az európai gazdasági közösség és a NATO is. A stabilitás és a nemzeti függetlenség még nem látszott egymást kiegészítö feltételnek, a rossz, de kiszámítható világból egy kiszámíthatatlanba való átmenet nem látszott veszélytelennek. Nem véletlen, hogy 1989 júliusában az amerikai politika azon mesterkedett, hogy hatalmon tartsa Wojciech Jaruzelskit, akit washingtoni látogatásra hívtak, miután a 
lengyel választáson a kommunisták megsemmisítő vereséget szenvedtek. Az amerikai politikai paradigma váltása valamikor 1990 tavaszán kezdődött, amikor kezdett világossá válni, hogy a szovjet térségben kialakuló biztonsági ürt Amerikának kell betöltenie.

Mindebböl az következik, hogy a kommunista rendszer összeomlása és a Varsói Szerződés felszámolása nem kizárólag a nemzetközi politika átrendeződésének volt a következménye, hanem a lengyel és a magyar belpolitikai átalakulásé is, amely a nemzetközi rend megváltozásához, egyebek között a német egyesítéshez vezetett. A német egyesítésre nem kerülhetett volna sor, ha a magyar vezetés nem egyezik bele az NDK állampolgárok átengedésébe Ausztriába, ami destabilizálta a kelet-német államot. Az erről szóló döntés azonban nem egyik pillanatról a másikra született meg, és nem is legfelül, hanem a pártvezetés, az ellenzék, a civil társdalom különböző szintjein érlelődött. Kis lépések - előre nem látható és nem is feltétlenül kívánt - kumulatív eredménye volt a határ megnyitásáról szóló döntés, mely tükrözte az egész átalakulás dinamikáját. Végső soron tehát olyan kis államokból indult el a nemzetközi átrendeződés, amelyek korábban nem rendelkezhettek a nemzetközi térben elfoglalt helyükről. Itt tehát többről van szó, mint a gyengék nyomásgyakorló képességéröl. Felmerül a kérdés: milyen körülmények között kerülhetett sor arra, hogy az érintett országok kilépjenek a szovjet hegemonikus tér által szabott kényszerzubbonyból?

1988-ban a Varsói Szerződés politikai tanácskozó testületének ülésén Eduard Sevardnadze, a Szovjetunió külügyminisztere fontos bejelentést tett: a Szovjetunió elvesztette a hidegháborút. Mindez a nemzetközi politika szabályai szerint arra indíthatta a vesztes fél szövetségeseit, hogy egy erősebb hegemón hatalom mellett keressék biztonságukat. Nem beszélve arról, hogy a gorbacsovi reform kudarcát nyögő szovjet gazdaság már arra sem volt képes, hogy kifizesse a KGST-ből oda áramló árukat és még kevésbé arra, hogy az eladósodottság tengerében fuldokló kliensállamokat, Magyarországot és Lengyelországot kölcsönökkel mentse ki a pénzügyi bajból. Gorbacsov kutyaszorítóban volt. Politikai ellenfelei azzal vádolták, hogy leépíti a Szovjetunió stratégiai hadállásait, ugyanakkor viszont, ha katonai eszközökhöz nyúlt volna, saját reformtörekvéseit érvénytelenítette volna. Tény, hogy végzetesen meggyengült a szovjet hatalmi tér, melyben a szovjet kliensállamoknak müködniük kellett. A gazdasági és politikai válságot átélő Szovjetuniót a közép-európai események is gyengítették, hiszen azok tovább erősítették a szovjet bomlási folyamatot. A közép-európai gyenge államok olyan esetekben voltak képesek befolyásolni a nemzetközi politikát, amikor a nagyhatalmaknak nem állt módjukban erőt kifejteni a térségben. A közép-európai kisállamok érdekérvényesítő képessége a hatalmi tér fluktuációjának és belső átalakulásuknak függvénye lehetett. 


\section{IRODALOM}

Bull, H. (1977): The Anarchical Society. New York: Columbia University Press

Gourevitch, P. (1978): The Second Image Reversed: The International Sources of Domestic Politics. International Organization, 32, 4, 881-912.

Jervis, R. (2002): The Security Dilemma. World Politics, 30, 2, 167-214.

Lojkó M. (2010): Conservative Realignment in British Policy on Central Europe and the Balkans During the Early Interwar Years. In: Borhi L. (szerk.): Európa, nemzet, külpolitika-tanulmányok Ádám Magda 85. születésnapjára. Budapest: Aura Kiadó, 153-170.

Morganthau, H. J. (1948): Politics Among Nations. New York: A. A. Knopf

Trachtenberg, M. (2012): The Cold War and After - History, Theory and the Logic of International Politics. Princeton, N. J.: Princeton University Press 